ISSN 0258-7122 (Print), 2408-8293 (Online)

Bangladesh J. Agril. Res. 41(1): 17-39, March 2016

\title{
PRODUCTIVITY AND PARTIAL BUDGET ANALYSIS IN WHEAT- RICE SEQUENCES AS INFLUENCED BY INTEGRATED PLANT NUTRITION SYSTEM AND LEGUME CROPS INCLUSION
}

\author{
MD. SHAKHAWAT HOSSAIN ${ }^{1}$, M. A. R. SARKAR ${ }^{2}$, M. JAHIRUDDIN ${ }^{3}$ \\ A. K. CHAKI ${ }^{4}$ AND ASM M. R. KHAN ${ }^{4}$
}

\begin{abstract}
The experiments were carried out at the Regional Wheat Research Centre, Rajshahi of Bangladesh Agricultural Research Institute (BARI) for two consecutive years, 2009-10 and 2010-11 to evaluate the agro-economic productivity of Wheat-Rice cropping sequence as influenced by integrated plant nutrition system (IPNS) and inclusion of legume crops. The experiment comprised of four cropping sequences viz. Wheat-Mungbean- T. Aman rice, Wheat-Blackgram- T. Aman rice, Wheat-Sesbania- T. Aman rice and WheatFallow- T. Aman rice; and six nutrient treatments viz. $100 \%$ recommended nutrient rates, IPNS with $3 \mathrm{t} \mathrm{ha}^{-1}$ poultry manure (PM), IPNS with $6 \mathrm{t} \mathrm{ha}^{-1} \mathrm{PM}$, IPNS with $5 \mathrm{t} \mathrm{ha}^{-1}$ cowdung (CD), IPNS with $10 \mathrm{t} \mathrm{ha}^{-1} \mathrm{CD}$ and farmers' practice (FP). It was carried out in a split-plot design assigning cropping sequences in the main plots and nutrient treatments in the sub-plots with three replications. For the IPNS, the $100 \%$ nutrient rates were adjusted with manure and fertilizers. Inclusion of mungbean in the Wheat-Rice cropping sequence showed higher production cost but it gave higher system productivity, gross return, gross margin, benefitcost ratio and production efficiency. This cropping sequence gave on an average $57 \%$ higher wheat equivalent yield (WEY) compared to the existing Wheat-Rice sequence followed by blackgram included cropping sequence. The IPNS based fertilizer and manure application had better yield performance, WEY, gross margin, gross return, benefit-cost ratio, production efficiency and land use efficiency as compared to $100 \%$ chemical fertilizers or FP. It is concluded that the Wheat-Mungbean-Rice cropping sequence with IPNS approach is a productive and profitable technology for crop cultivation.
\end{abstract}

Keywords: Wheat-Rice sequence, crop productivity, production efficiency, land use efficiency and partial budget analysis.

\section{Introduction}

Wheat and rice are major cereals contributing to food security and income in South Asia. The rice-wheat systems occupy about 0.4 million ha in Bangladesh (Timsina et al., 2010). Rice and wheat contribute $97 \%$ of total food grain production (BBS, 2012) and 94\% of the national calorie intake in Bangladesh (Timsina and Connor,

${ }^{1}$ On-Farm Research Division, Barind Station, Bangladesh Agricultural Research Institute (BARI), Rajshahi-6000, ${ }^{2}$ Department of Agronomy, Bangladesh Agricultural University (BAU), Mymensingh-2202, ${ }^{3}$ Department of Soil Science, BAU, Mymensingh-2202, ${ }^{4}$ OnFarm Research Division, BARI, Gazipur-1701, Bangladesh. 
2001). Bangladesh produced about 1.0 million ton of wheat with a productivity 2.6 $\mathrm{t} \mathrm{ha}^{-1}$ and 12.80 million tons of Transplant Aman rice with a productivity of $2.3 \mathrm{t}$ $\mathrm{ha}^{-1}$ in 2010-11 (BBS, 2012) but productivity is below the potential yield of 4-5 t $\mathrm{ha}^{-1}$ in wheat (BARI, 2011) and 5-6 $\mathrm{t} \mathrm{ha}^{-1}$ in Transplant Aman rice (BRRI, 2010). The continuous use of chemical fertilizers without nutrient recycling has led to an immense loss of soil fertility and productivity (Nand Ram, 2000). It has also been established that cereal-cereal sequences are more exhaustive and put a heavy demand on soil resources as compared to cereal-legume sequences (Singh et al., 2011). Studies by Bhandari et al. (2002) attributed the reduced productivity of the rice-wheat system to declining soil organic matter, decreased soil fertility, occurrence of nutrient imbalances and inappropriate fertilizer practices.

Soil organic matter (SOM) is the key factor for sustainable soil fertility and crop productivity. Organic materials, such as crop residues, green manure (GM) and animal manure, and their continuous use have a strong influence on soil productivity (Timsina and Connor, 2001; Schmidt and Merbach, 2004; YadvinderSingh et al., 2008). The wheat-rice production system generates a large amount of crop residues annually. Traditionally, wheat and rice straw have removed from the fields for use as cattle feed and for several other purposes such as livestock bedding, thatching material for house and fuel (Samra et al., 2003). Inclusion of legume crops as green manure or grain legume in the system has been found more beneficial than wheat-rice sequence (Singh et al., 2011). Legume crops fix atmospheric $\mathrm{N}$, enrich soil fertility and could help to sustain the long-term productivity of cereal-based cropping systems. It has been well documented that the rice-wheat cropping system can be diversified using grain legume or Sesbania for green manure as a substitute crop (Bohra et al., 2007). Livestock manure provides $\mathrm{N}, \mathrm{P}, \mathrm{K}, \mathrm{S}$ and many trace minerals as well as serving as a soil conditioner by increasing organic matter and improving soil porosity and water holding capacity (Eghball et al., 2002). Application of cowdung is common in Bangladesh, but availability of cowdung has been declining because of animal power is being replaced by power-tiller (small mechanization) resulting in reduced livestock as well as cowdung and farmyard manure (FYM) production. In Bangladesh, poultry industry has remarkably grown which has facilitated a use of poultry manure (PM) because it contains a high concentration of nutrients, addition of even a small quantity, in an integrated manner or alone, could meet the shortage of cowdung or FYM to some extent.

Sustainable production of a crop can not be maintained by using the chemical fertilizer alone and similarly it is not possible to obtain high yield by using only organic manure (Bair, 1990). Kumar and Goh (2000) reported that no single manure management practice is superior under all conditions. The system productivity may become sustainable through integrated use of organic and inorganic sources of nutrients (Singh and Yadav, 1992). In this respect, Integrated 
Plant Nutrition System (IPNS) can be a good approach to combat nutrient depletion and promote sustainable crop production. Therefore, the present study was undertaken to evaluate the diversification of Wheat-Rice cropping sequence in respect to IPNS based nutrient management on sustaining productivity, production efficiency, land use efficiency and cost and return analysis.

\section{Materials and Method}

A two-year wheat-rice cropping sequence experiment was established in high land with medium permeability at Regional Wheat Research Centre, Rajshahi of Bangladesh Agricultural Research Institute (latitude $28^{0} 22^{\prime} \mathrm{N}$; longitude $88^{0} 39^{\prime} \mathrm{E}$; 20 m elevation) during November, 2009 to October 2011. The experimental site belonged to the agro-ecological zone of High Ganges River Floodplain (AEZ-11). The soil was silty clay loam with alkaline in nature $(8.4 \mathrm{pH})$ having very low organic matter $(0.81 \%)$. The total $\mathrm{N}$ and available $\mathrm{Zn}$ were also very low while the available $\mathrm{P}$, available $\mathrm{S}$ and exchangeable $\mathrm{K}$ status were medium. The available $\mathrm{B}$ content was low. The chemical characteristics of the initial soils are presented in Table 1a.

The treatments were composed of four cropping sequences viz. 1) W-M-R: Wheat (Triticum aestivum L.)-Mungbean (Vigna radiata L.)- Rice (Oryza sativa L.), 2) W-B-R: Wheat -Blackgram (Phaseolus mungo L.) - Rice, 3) W-S-R: Wheat Sesbania (Sesbania aculeata L.) - Rice, and 4) W-F-R: Wheat -Fallow -Rice; and six nutrient treatments: 1) STB: $100 \%$ recommended fertilizer dose (soil test and high yield goal basis), 2) IPNS( $\left.\mathrm{PM}_{3}\right)$ : Integrated plant nutrition system (IPNS) with $3.0 \mathrm{t} \mathrm{ha}^{-1}$ poultry manure (PM), 3) IPNS(PM PM $_{6}$ IPNS with $6.0 \mathrm{t} \mathrm{ha}^{-1} \mathrm{PM}$, 4) IPNS(CD $)$ : IPNS with $5.0 \mathrm{t} \mathrm{ha}^{-1}$ cowdung $\left.(\mathrm{CD}), 5\right) \operatorname{IPNS}\left(\mathrm{CD}_{10}\right)$ : IPNS with 10.0 $\mathrm{t}$ ha ${ }^{-1} \mathrm{CD}$, and 6) FP: Farmers' Practice. The experiment was conducted in splitplot design where cropping sequence assigned in main plot and nutrient treatment in sub-plot. In the W-M-R and W-B-R sequences mungbean and black gram were used as grain legumes. After picking of pod the remaining plant parts were chopped and incorporated in the experimental plot in-situ. In W-S-R sequence, sesbania was ploughed down in-situ before flowering at 60 days after sowing at green stage as green manure. For STB treatment only chemical fertilizer was applied. The amount of mineralizable nutrients in PM and CD were deducted from STB based nutrient rates and adjusted accordingly as per different IPNS treatments (BARC, 2005). Thus the amount of $\mathrm{N}, \mathrm{P}$ an $\mathrm{K}$ was virtually same for treatments STB, IPNS( $\left(\mathrm{PM}_{3}\right)$, IPNS( $\left(\mathrm{PM}_{6}\right)$, IPNS( $\left(\mathrm{CD}_{5}\right)$ and IPNS( $\left(\mathrm{CD}_{10}\right)$. In IPNS approach, $3 \mathrm{t}$ $\mathrm{ha}^{-1} \mathrm{PM}$ or $5 \mathrm{t} \mathrm{ha}^{-1} \mathrm{CD}$ was economic for crop production (OFRD, 2009). The FP treatment was determined on the interactions with representative local farmers prior to start of the experiment. Crop cycle was started with wheat as the first crop in late November 2009. Cowdung and poultry manure were applied to the wheat crop only. Fertilizer doses of mungbean and blackgram were calculated and rationalized 


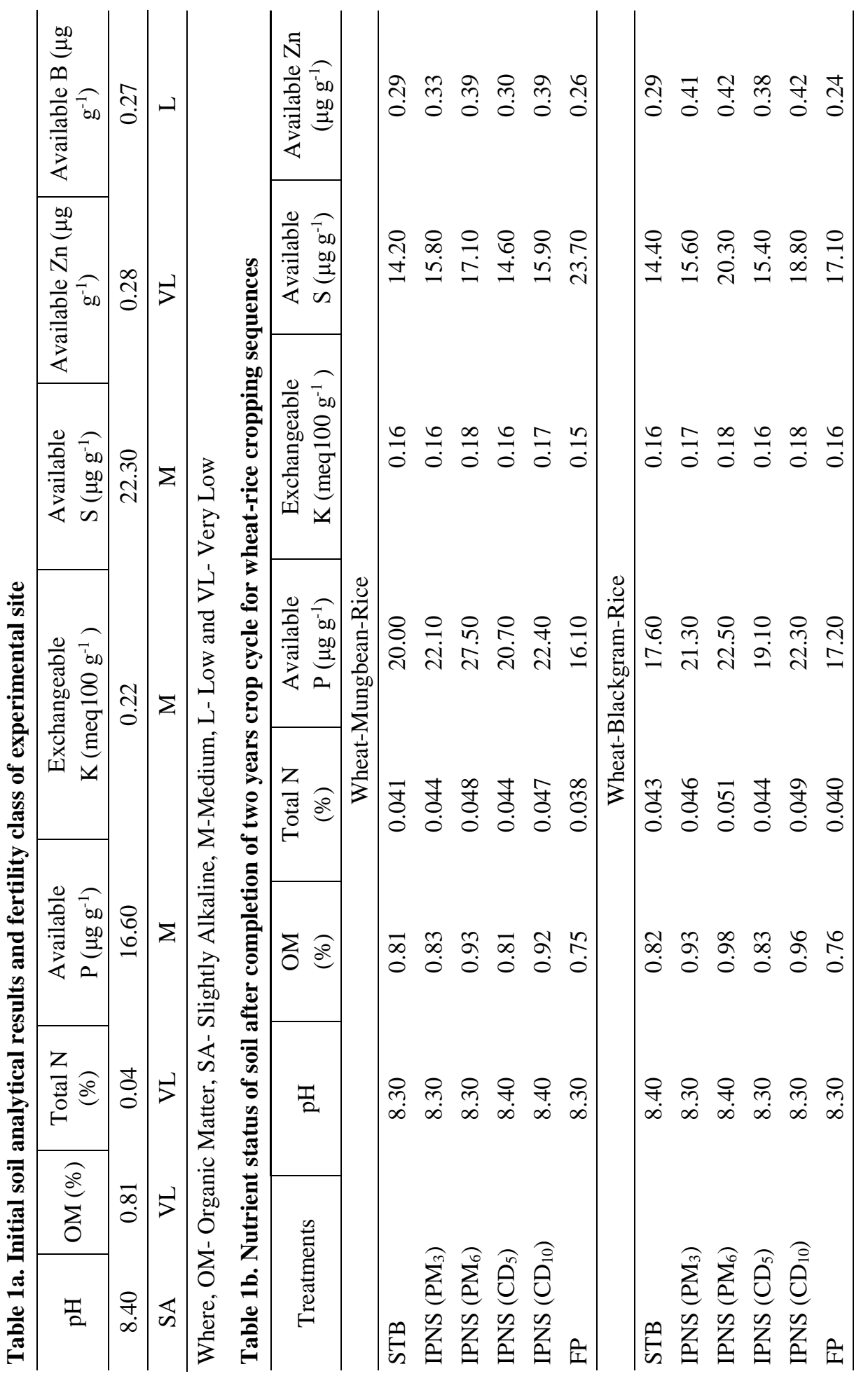




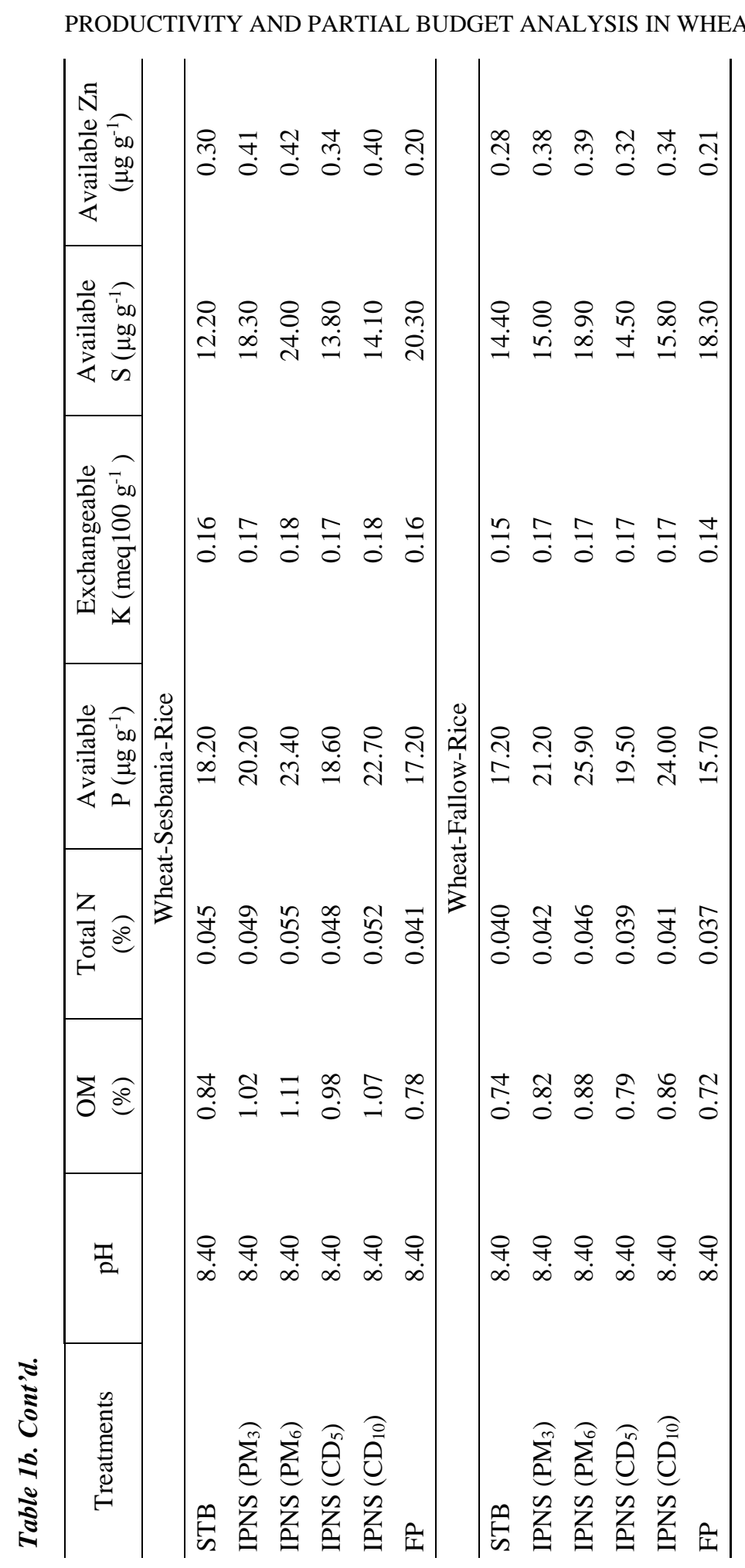


considering residual effect of nutrient (except $\mathrm{N}$ ) applied to previous crop (wheat) (BARC, 2005). Sesbania was grown without any fertilizer. Fertilizer doses of rice were calculated and rationalized on the basis of total cropping pattern. For rice, the reduction of $\mathrm{P}$ and $\mathrm{K}$ from the calculated dose was due to the residual effect and $\mathrm{N}$ reduction due to addition of legume residues incorporation. The fertilizer dose for FP was not rationalized. Organic manures (PM and CD) were applied on a dry weight basis. Nutrient management treatments for different cropping sequences are presented in Table 2. After final land preparation all the plots and sub-plots were separated by earthen banks line with plastic polythene to a height of about 30 $\mathrm{cm}$ to avoid nutrient transfer between adjacent plots by lateral seepage.

The crop cultivars were grown on a permanent layout. Rice was transplanted into well-puddled soil, and all other crops were sown by hand. Wheat (cv. BARI Gom24), mungbean (cv. BARI Mung6), blackgram (cv. BARI Mash3), Sesbania (cv. local Dhaincha) and rice (cv. BRRI dhan49) were seeded/planted with 20-cm row spacing for wheat; plant spacings were $30 \times 10 \mathrm{~cm}$ for mungbean/ blackgram, broadcasting for Sesbania @ $60 \mathrm{~kg} \mathrm{ha}^{-1}$, and $25 \times 15 \mathrm{~cm}$ for rice. Wheat was sown in late November, mungbean/blackgram in early April, Sesbania in early May and rice was transplanted in early to mid July in each year. For rice, all fertilizers except $\mathrm{N}$ was broadcast and incorporated at the time of final land preparation. Nitrogen was broadcast in three equal splits at 15, 30 and 45 days after transplanting. For wheat, full dose of all fertilizers and two-thirds of $\mathrm{N}$ including organic manure were applied at sowing. The remaining $\mathrm{N}$ was top-dressed at crown-root initiation (CRI) stage. For the other crops, all fertilizers were applied at sowing. Crop residues from legume crops (mungbean, blackgram and sesbania) were chopped and incorporated into the soil 8-10 days prior to rice transplanting. At each year wheat received three irrigations of approximately $75 \mathrm{~mm}$ each at CRI, maximum tillering (MT), and grain filling (GF) stages. For rice, a total $792.2 \mathrm{~mm}$ of precipitation was occurred in first year 2009-2010. So more irrigation was applied each time $(150 \mathrm{~mm})$ by flood method but no irrigation was done during the growing period of rice except puddling period in 2010-2011. Before sowing of legume crops, light irrigation (about $50 \mathrm{~mm}$ ) was given to the field for providing necessary soil moisture in both the years. Crop management, including weeding and pesticide was given to support the normal growth of crops.

Yield of main and by-product of each crop under various cropping sequences were measured in each plot $\left(6 \mathrm{~m}^{2}\right)$ at physiological maturity. The economic part of individual crops was separated manually after harvesting. Grain yield for wheat and grain legume was adjusted at $12 \%$ moisture while for rice at $14 \%$ moisture from the harvested area. 


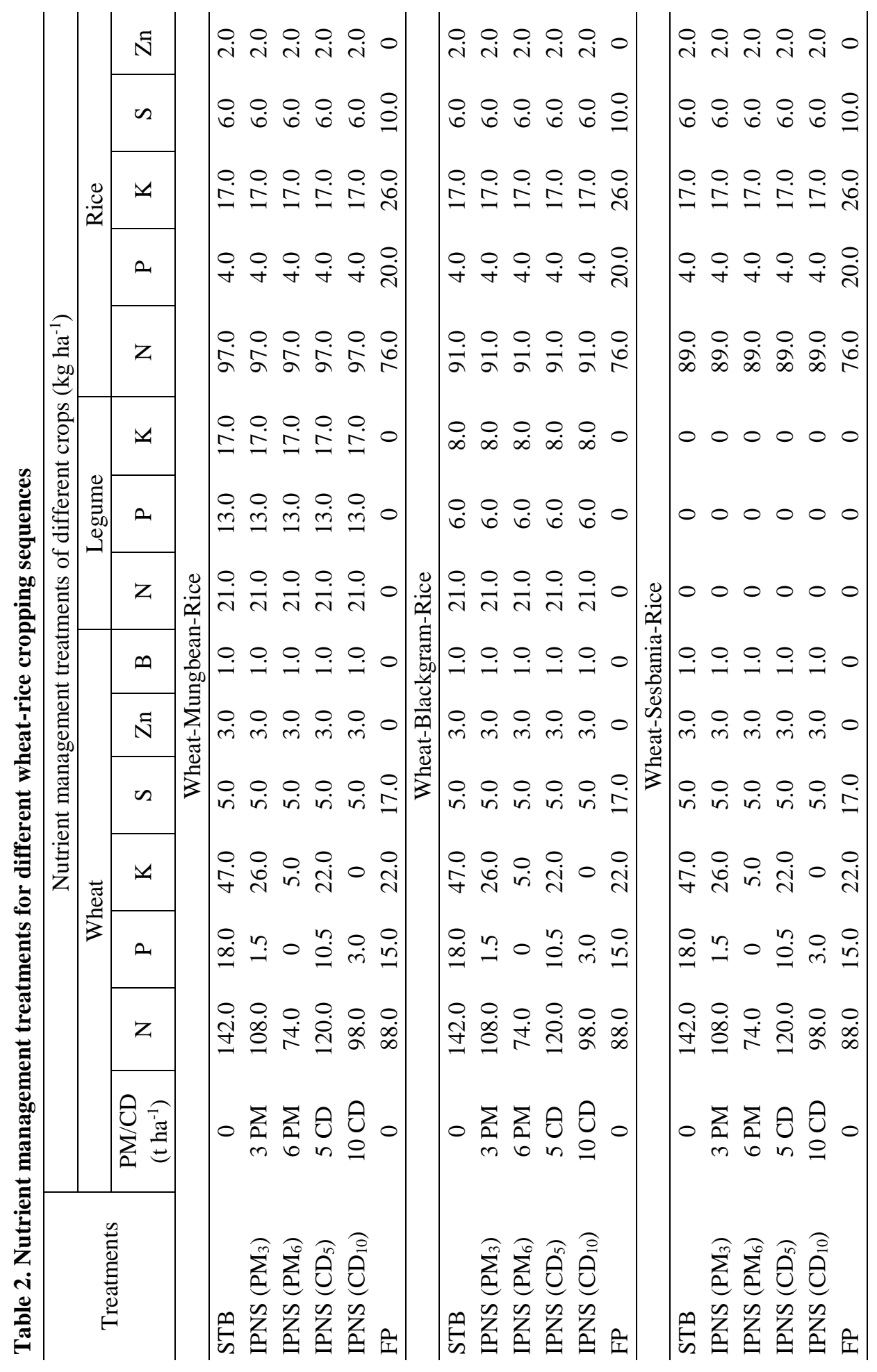




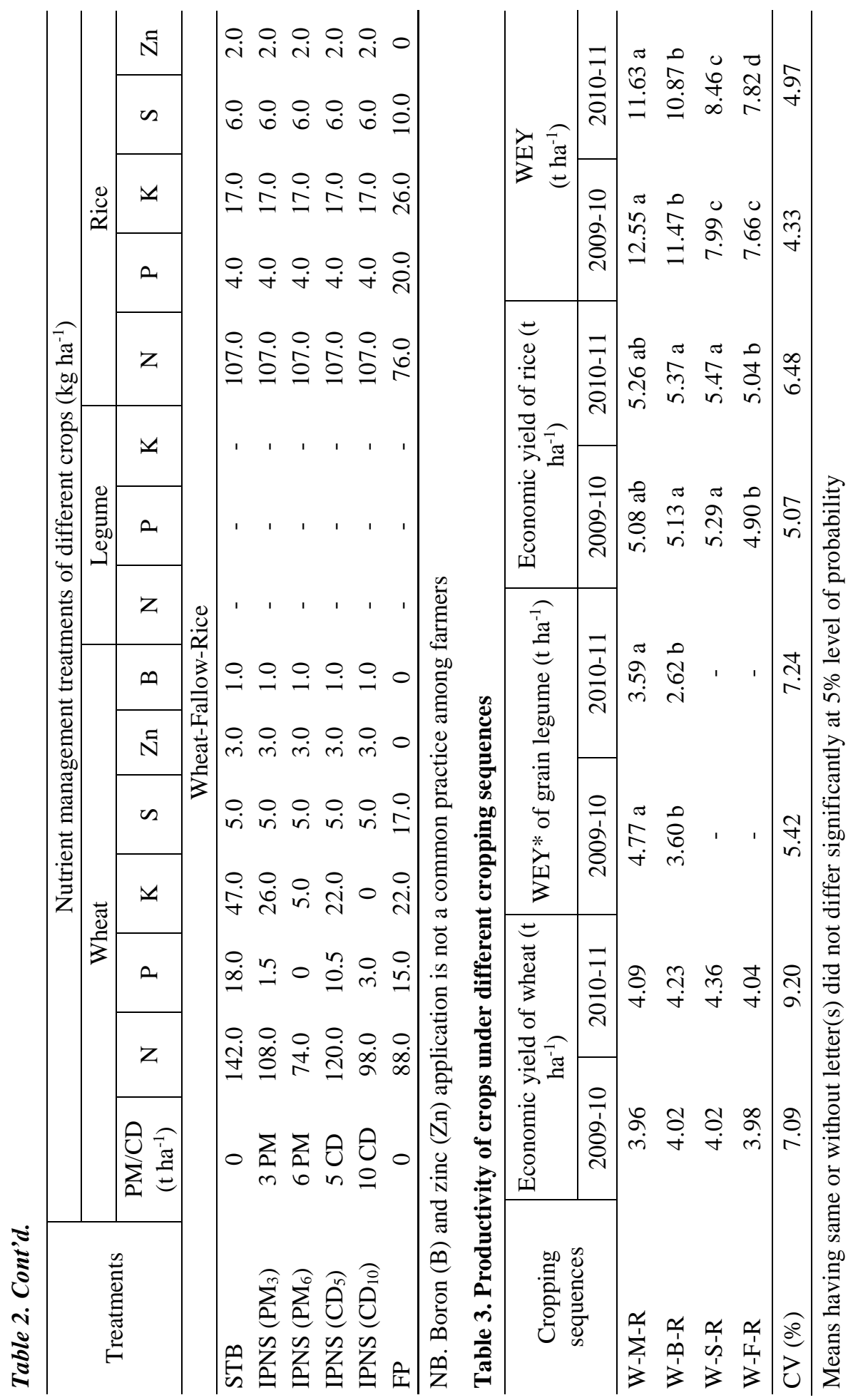


The productivity of different cropping sequences was compared by calculating their economic wheat equivalent yield (WEY) using formula given by Ahlawat and Sharma (1993), where

$$
\text { WEY }=\frac{\text { Yield of each crop }\left(\mathrm{t} \mathrm{ha}^{-1}\right) \times \text { Economic value of respective crop }\left(\mathrm{Tk} \mathrm{t}^{-1}\right)}{\text { Price of wheat grain }\left(\mathrm{Tk} \mathrm{t}^{-1}\right)}
$$

Land use efficiency (LUE) was estimated total duration of crops in the sequence by 365 days and expressed in \% (Jamwal, 2001).

$$
\text { LUE }=\frac{\sum \text { Dc }}{365}
$$

Where, $\mathrm{Dc}=$ Duration of crops in the sequence.

Production efficiency (PE) was calculated by taking total economic yield of the sequence on wheat equivalent basis divided duration of crops (Jamwal, 2001).

$$
\begin{aligned}
& \text { PE }=\text { WEY } \\
& \text { Where, } \\
& \mathrm{WEY}=\text { Wheat equivalent yield in a sequence } \\
& \mathrm{Dc}=\text { Duration of crops in that sequence. }
\end{aligned}
$$

The partial budget analysis was done for gross return, gross margin and benefit cost ratio following the method suggested by Perrin et al. (1979). Data on crop measured parameters of different crops for each year were subjected to statistical analysis through MSTAT-C software and the mean comparisons were made by DMRT at 5\% level (Gomez and Gomez, 1984).

\section{Results and Discussion}

Monthly maximum and minimum air temperature and rainfall data are presented for each of the two years (2009-2011) in Fig. 1. There was a large difference in annual rainfall from where in 2009-2010, total rainfall was $792.2 \mathrm{~mm}$ but it was $1596.8 \mathrm{~mm}$ in 2010-2011. In both years, most rainfall occurred during April to October which ranged from 40 to $465 \mathrm{~mm}$. Yearly variation of rainfall affected on crop productivity specially yield of grain legume. Maximum and minimum air temperatures also varied from year-to-year where in 2010-2011, a relatively cold period commenced in March and persisted, compared with 2009-2010, until September. This low temperature was due to cloudy and wet (monsoon) season in second year. 
There was incidence of jute hairy caterpillar (Spilosoma obliqua), especially in blackgarm plots in the second year. Substantial rain, together with winds in that year caused lodging in some plots of rice. The heavy rainfall $(1596 \mathrm{~mm})$ in the second year might have resulted loss of nutrients but losses could not be studied.
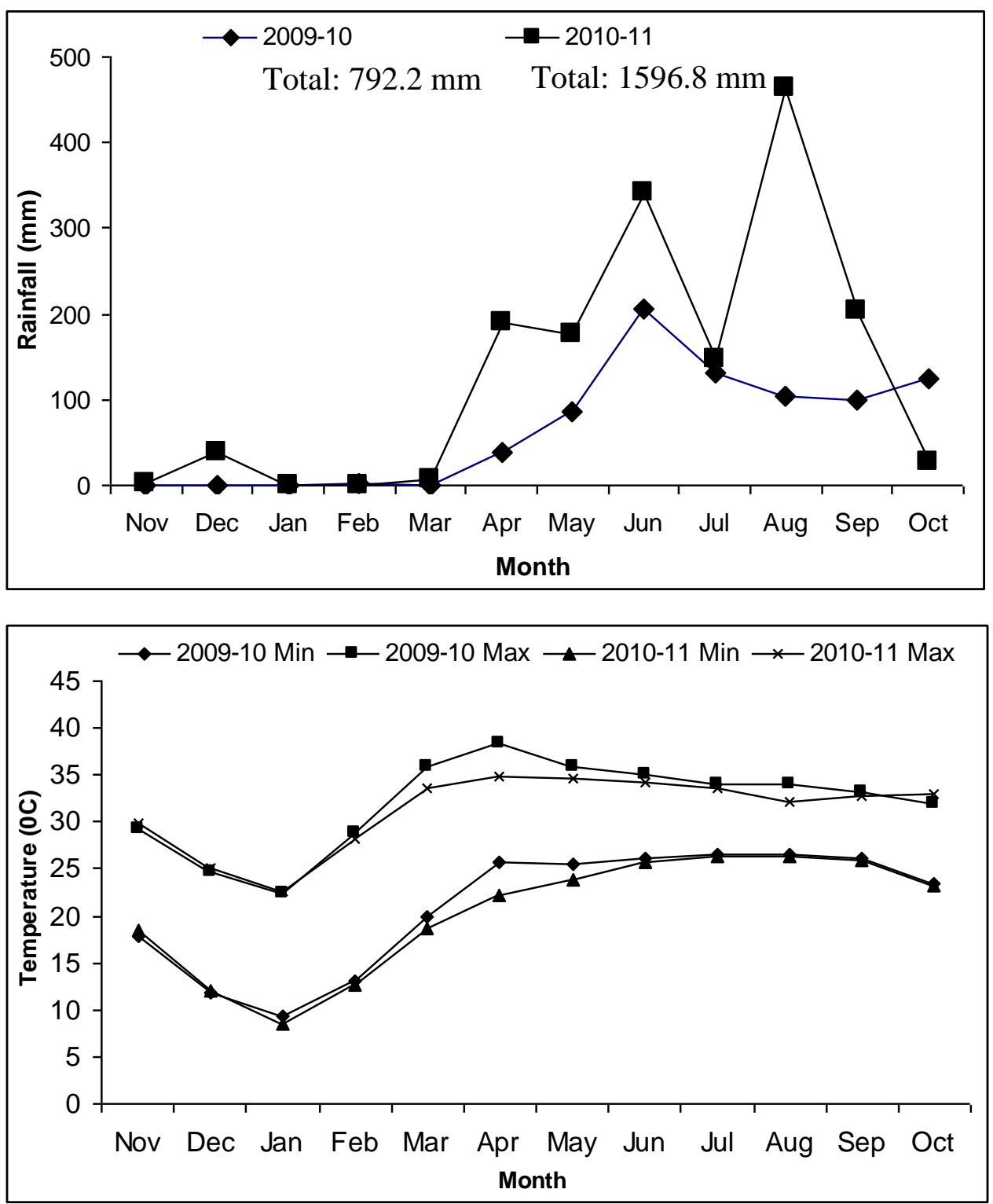

Fig. 1. Rainfall and temperature (maximum and minimum) of the study area during 2009-2010 and 2010-2011 seasons. 


\section{Soil fertility}

After two years cycle, there was a very small decrease in soil $\mathrm{pH}$ in $\mathrm{W}-\mathrm{M}-\mathrm{R}$ and W-B-R cropping sequences compared to the initial value (Table 1b). This reduction in $\mathrm{pH}$ occurred possibly due to the production of organic acids from the decomposition of biomass of herbaceous legumes (mungbean and blackgram) (Chadha et al., 2009). Soil pH remained the same in W-S-R and W-F-R sequences. Generally, soil organic matter (SOM) in soil increased in crop sequences in which legumes had been included. This was more evident in the W-S-R sequence, in which sesbania was included. SOM in the W-F-R sequence decreased slightly, presumably due to the lack of legumes. SOM improved considerably in OMamended plots over the initial value, the increase being more pronounced when a higher level of OM was applied. On the other hand, SOM decreased in STB and FP. The inclusion of legumes in W-S-R, W-B-R and W-M-R sequences improved soil $\mathrm{N}$ but declined slightly in W-F-R compared to the initial value, indicating that the use of a legume in these three crop sequences increased the total $\mathrm{N}$ content. Similar to SOM, the application of OM enhanced total N in manure-treated (CD, PM) plots more than STB or FP. However, the cumulative effect of OM and legume residue resulted in more positive gains in total $\mathrm{N}$. Total $\mathrm{N}$ in FP soil decreased in the W-F-R and W-M-R sequences, but increased in W-S-R. Compared with the initial value, the available $\mathrm{P}$ content of soil increased in all sequences and was almost similar. All nutrient treatments except FP showed a significant increase in available $\mathrm{P}$. The highest available $\mathrm{P}$ was recorded in IPNS $\left(\mathrm{PM}_{6}\right)$ plot. The W-F-R sequence, when using FP, showed a significant decreased in $\mathrm{P}$. In contrast to $\mathrm{P}$, exchangeable $\mathrm{K}$ was markedly depleted in all crop sequences, after two crop cycles, relative to initial soil. Among these, the largest depletion was noticed when FP was used in the W-F-R sequence. These results indicate that there was a higher uptake of $\mathrm{K}$ than the amount added, which may lead to a serious depletion of $\mathrm{K}$ in the long term. Similar to $\mathrm{K}$, the available $\mathrm{S}$ decreased in all cropping sequences and nutrient treatments after two crop cycles with the greatest depletion taking place in the W-F-R sequence. Available Zn content showed an increasing trend after the two crop cycles in response to different cropping sequences and nutrient management. But it became depleted when FP was applied to all sequences.

\section{Crop productivity}

The effect of cropping sequence on the yields of grain legume, rice and system productivity showed significant (Table 3). Yields of both mungbean and blackgram were converted to wheat equivalent yield (WEY). Between the grain legumes mungbean gave higher WEY in comparison with blackgram in both years. The increase in WEY in mungbean over blackgram was 33 and 37\% during 200910 and 2010-11, respectively. This variation is due to higher yield potentiality and grain price of mungbean than blackgram. However, grain yield of legume crop 
varied significantly from year to year where in second year, periods of heavy rainfall that severely reduced the grain yields of mungbean and blackgram. These results are in agreement with findings reported by Rahman (1991) and Quayyum et al. (2002). The highest grain yield of rice was observed in W-S-R (5.29 $\left.\mathrm{t} \mathrm{ha}^{-1}\right)$ followed by W-B-R $\left(5.13 \mathrm{t} \mathrm{ha}^{-1}\right)$ and W-M-R $\left(5.08 \mathrm{tha}^{-1}\right)$ and the lowest in W-F$\mathrm{R}\left(4.90 \mathrm{t} \mathrm{ha}^{-1}\right)$ in 2009-10. Similar trend was observed for economic yield of rice in 2010-11. Grain yield increased in W-S-R, W-B-R and W-M-R by 8, 5 and $4 \%$, respectively, over W-F-R in 2009-10. Contrary, grain yields increased in W-S-R, W-B-R and W-M-R by 9, 7 and 4\%, respectively over W-F-R in 2010-2011. Overall preceded legume inclusion sequences produced higher grain yield while the lowest yield was obtained in the seasonal fallow sequence in both years. It was observed that the yield components (number of effective tillers hill ${ }^{-1}$ (9 to 12) and grains panicle ${ }^{-1}$ (124 to 132)) were improved due to legume residue recycling which ultimately increased grain yield compared to the seasonal fallow sequence (number of effective tillers hill ${ }^{-1}$ (8 to 10$)$ and grains panicle ${ }^{-1}$ (115 to 117)). Nitrogen and other nutrients contributed through legume residue recycling might be the reason for increase of grain yield. Prasad et al. (1999) and Sharma and Prasad (1999) reported that yield benefits from legume crops ranging from 16 to $115 \%$ to the immediate rice crop. Legume residue could meet $\mathrm{N}$ needs of high yielding rice cultivars, and could show synergetic effects in increasing rice growth and yield (Yadvinder-Singh et al., 2004). The W-M-R sequence recorded significantly the highest system WEY $\left(12.55 \mathrm{t} \mathrm{ha}^{-1}\right.$ in $2009-10$ and $11.63 \mathrm{t} \mathrm{ha}^{-1}$ in 2010-11) than rest of the sequences during both years. Higher grain yield of mungbean after wheat was attributed for attaining highest system WEY by this sequence. The mungbean in wheat-mungbean-rice sequence markedly contributed to the system enhancing the productivity of succeeding crops and consequently resulted in significantly higher WEY than that of the wheat-rice system alone or with green manuring (Singh et al., 2011). The W-S-R (7.99 $\left.\mathrm{t} \mathrm{ha}^{-1}\right)$ and W-F-R (7.66 $\mathrm{t} \mathrm{ha}^{-1}$ ) systems were found to be equally effective during 2009-10. During 201011 , they differed significantly with the higher in W-S-R $\left(8.46 \mathrm{t} \mathrm{ha}^{-1}\right)$. Sesbania, after harvesting of wheat, contributed to sequence besides benefiting the succeeding rice and consequently resulted in significantly higher WEY than W-F$\mathrm{R}$ sequence. Sequence W-F-R $\left(7.82 \mathrm{t} \mathrm{ha}^{-1}\right)$ gave the lowest WEY among the sequences in 2010-11. Total productivity increased by 64,50 and $4 \%$ in 2009-10 and 49,39 and $8 \%$ in 2010-11 in W-M-R, W-B-R and W-S-R, respectively over W-F-R.

The effect of nutrient treatment on economic yields of wheat showed significant in both years (Table 4). Wheat yield tended to be higher in the packages involving organic manure. In 2009-10, all the treatments had a yield in a range of 3.03 to $4.55 \mathrm{t} \mathrm{ha}^{-1}$. Among all the different packages, IPNS $\left(\mathrm{PM}_{6}\right)$ produced maximum grain yield $\left(4.55 \mathrm{t} \mathrm{ha}^{-1}\right)$ followed by IPNS $\left(\mathrm{CD}_{10}\right)\left(4.38 \mathrm{t} \mathrm{ha}^{-1}\right)$ but FP showed the lowest yield (3.03 $\left.\mathrm{t} \mathrm{ha}^{-1}\right)$. The IPNS treatments combine of $\mathrm{PM}_{6}, \mathrm{CD}_{10}, \mathrm{PM}_{3}, \mathrm{CD}_{5}$ and STB treatment gave 50, 45, 40, 30 and 26\% higher economic yield, respectively over FP. In 2010-11, the treatments IPNS of $\mathrm{PM}_{6}, \mathrm{CD}_{10}$ and $\mathrm{PM}_{3}$ 
showed the maximum and similar yields which were $4.63,4.40$ and $4.38 \mathrm{t} \mathrm{ha}^{-1}$, respectively. The other treatments showed similar trend as was also observed in 2009-10 (Table 4). In this year, the treatments IPNS of $\mathrm{PM}_{6}, \mathrm{CD}_{10}, \mathrm{PM}_{3}, \mathrm{CD}_{5}$ and STB yielded 36, 29, 28, 24 and 17\%, respectively higher over FP. Higher grain yield of wheat in organic manure containing packages were mainly contributed by higher number of spikes plant ${ }^{-1}$ (1.5 to 2.0), grains spike ${ }^{-1}$ (40 to 45 ) and 1000grain weight ( 53 to $55 \mathrm{~g}$ ). Yield of wheat was higher with the IPNS treatments where integrated use of chemical fertilizer and organic manure might enhance growth and yield contributing characters due to slow and uninterrupted releasing of plant nutrient resulted to higher yield. Evidently, the recommended chemical fertilizer (STB) and farmers' dose (FP) was inadequate or unbalanced, as it lacked other essential nutrients including micronutrients (Behera, 2009). However, the better response to PM amended treatment than to cowdung (CD) may be ascribed to the higher nutrient content and lower $\mathrm{C}: \mathrm{N}$ ratio (11) leading to increased nutrient availability in soil (Shepherd and Withers, 1999). Shepherd and Withers (1999) also reported that PM is quite rich in N content. Poultry manure contained nearly $40 \%$ of total $\mathrm{N}$ in a relatively easily available form and resulted to higher yield. The effect of nutrient treatment on WEY of grain legume also showed significant in both years (Table 4). In 2009-10, the maximum WEY of grain legume was obtained from nutrient treatment IPNS $\left(\mathrm{PM}_{6}\right)\left(4.60 \mathrm{tha}^{-1}\right)$ which was statistically identical to IPNS $\left(\mathrm{CD}_{10}\right)\left(4.45 \mathrm{tha}^{-1}\right)$ and IPNS $\left(\mathrm{PM}_{3}\right)\left(4.32 \mathrm{t} \mathrm{ha}^{-1}\right)$. The treatments STB $\left(3.83 \mathrm{t} \mathrm{ha}^{-1}\right)$ and FP $\left(3.75 \mathrm{t} \mathrm{ha}^{-1}\right)$ yielded statistically similar WEY and the WEY of both grain legumes (mungbean and blackgram) was also higher in organic amended nutrient treatments. Tagoe et al. (2008) also found higher seed yield of soybean and cowpea with carbonized chicken manure. The effect nutrient treatment on rice yield was significant in both years (Table 4). The economic yield of rice was found maximum in IPNS $\left(\mathrm{PM}_{6}\right)$ followed by IPNS $\left(\mathrm{CD}_{10}\right)$, IPNS $\left(\mathrm{PM}_{3}\right)$ and IPNS $\left(\mathrm{CD}_{5}\right)$. The STB treatment gave lower rice yield with the lowest in FP in both years. Grain yield increased by $12,8,7,4$ and $2 \%$ in IPNS $\left(\mathrm{PM}_{6}\right)$, IPNS $\left(\mathrm{CD}_{10}\right)$, IPNS $\left(\mathrm{PM}_{3}\right)$, IPNS $\left(\mathrm{CD}_{5}\right)$ and STB, respectively over FP in 2009-2010. The corresponding yields increased over FP in 2010-2011 were 14, 13, 12, 11 and $7 \%$, respectively. Yield of rice was greater in IPNS with organic manures treatments due to positively responsive of number of effective tillers hill ${ }^{-1}$ ( 9 to 12) and grains panicle ${ }^{-1}$ (127 to 139). It showed that organics applied to preceding crop left significant quantity of nutrient for the succeeding crop. The residual effect of PM and CD on grain yield of rice during rainy season was almost comparable and significantly higher than inorganic indicating slow release of plant nutrient from manure. Hedge (1998) reported that organic source of nutrients applied to preceding crop can benefit the succeeding crop to a great extent. The results of the present study also showed that the rice responded more to PM than $\mathrm{CD}$. This was because of the fact that approximately $74 \%$ of total $\mathrm{P}$ and $40 \%$ of 


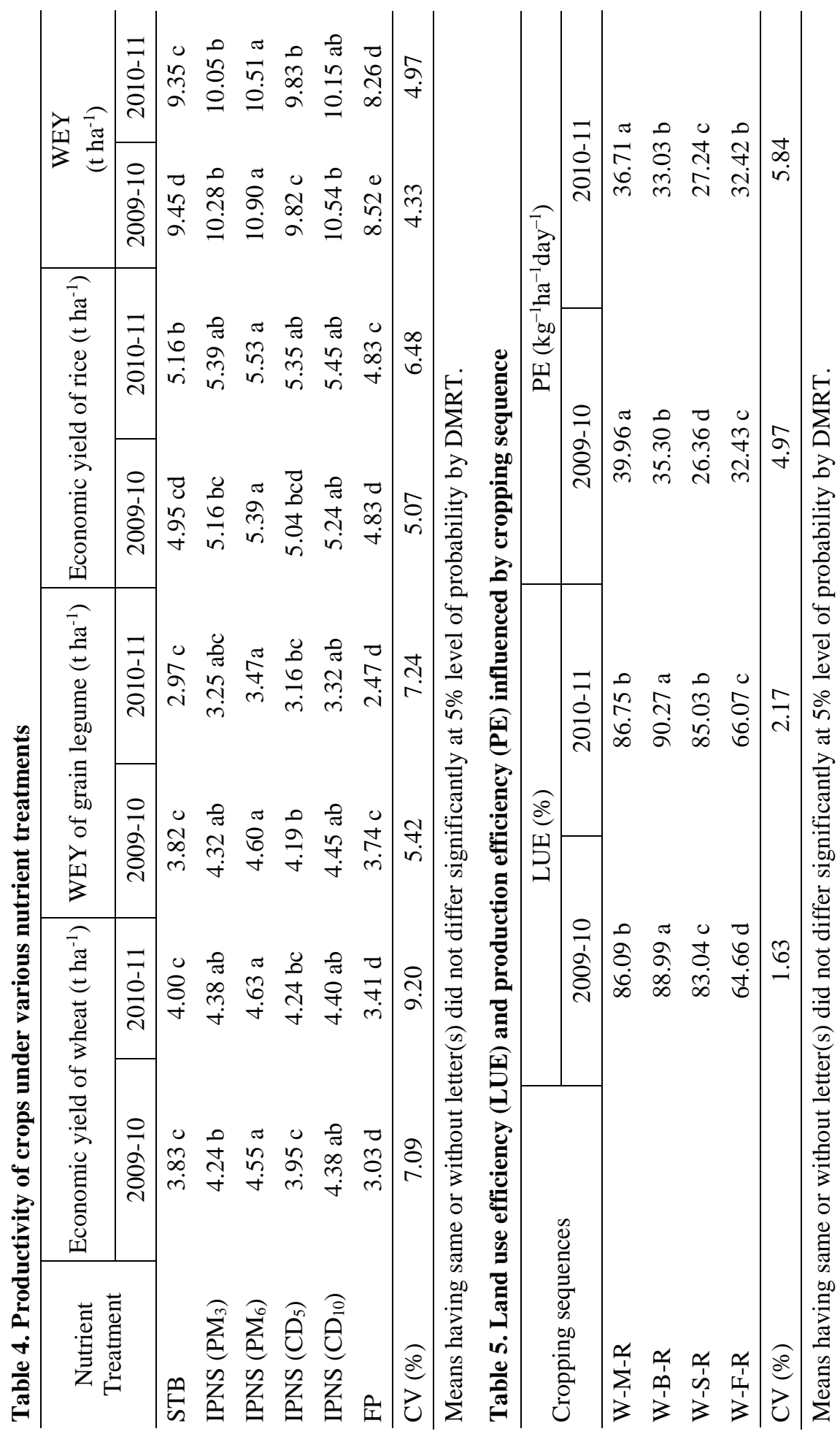



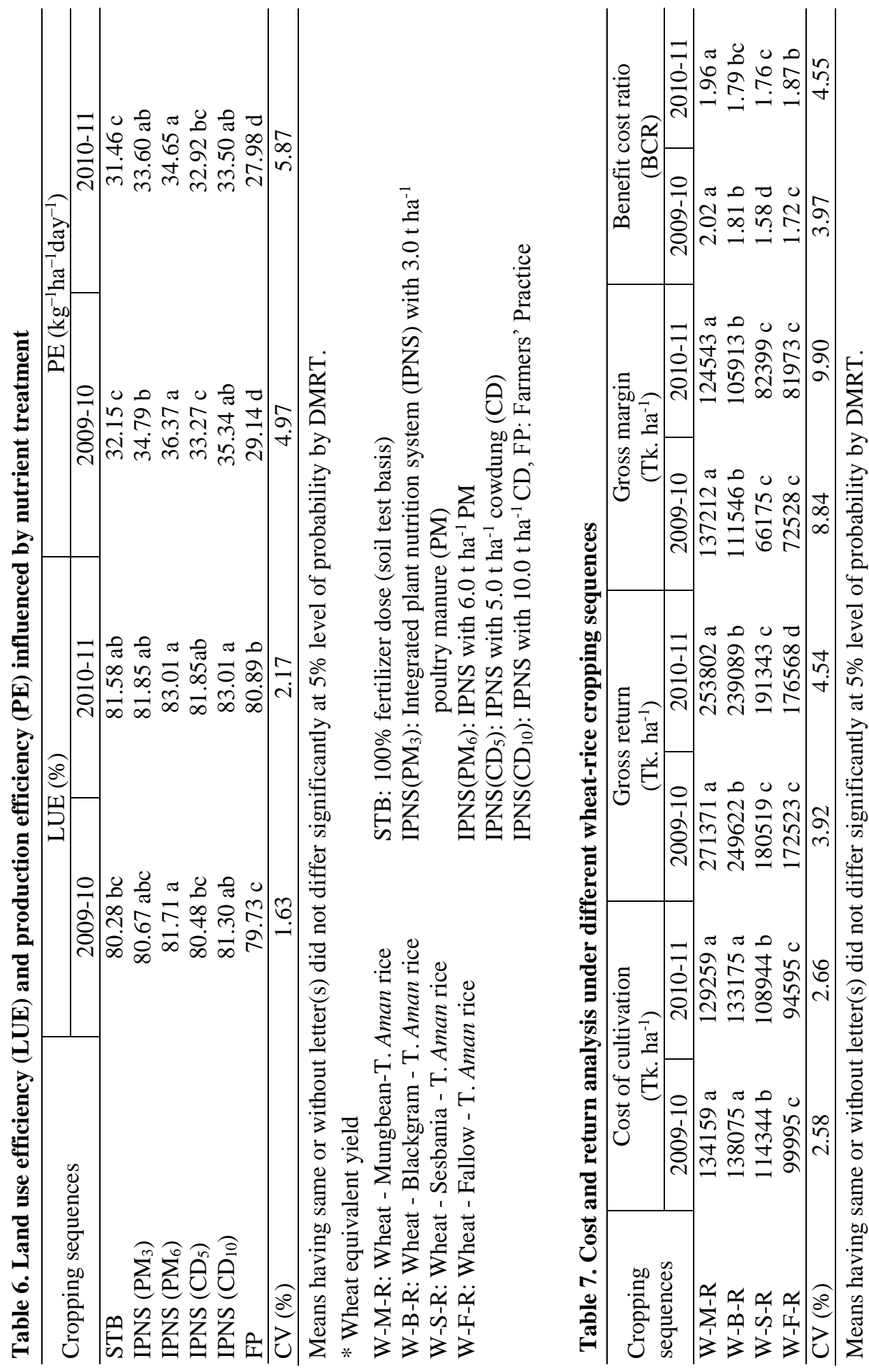
total N in PM were in available form (Shepherd and Withers, 1999). The system WEY by nutrient treatment varied significantly in both the years (Table 4). In 2009-10, the WEY in IPNS $\left(\mathrm{PM}_{6}\right)\left(10.90 \mathrm{t} \mathrm{ha}^{-1}\right)$ recorded the greatest among all other treatments. The WEY in IPNS $\left(\mathrm{CD}_{10}\right)$ and IPNS $\left(\mathrm{PM}_{3}\right)$ were 10.54 and 10.28 $\mathrm{t} \mathrm{ha}^{-1}$ which were statistically similar. The WEY in IPNS $\left(\mathrm{CD}_{5}\right)$ and STB were 9.82 and $9.45 \mathrm{tha}^{-1}$ which were significantly different. The lowest WEY was obtained from FP $\left(8.52 \mathrm{t} \mathrm{ha}^{-1}\right)$. During 2010-11, the trend of WEY was something different to previous year. In this year, nutrient treatments IPNS $\left(\mathrm{PM}_{6}\right)\left(10.51 \mathrm{t} \mathrm{ha}^{-1}\right)$ and IPNS $\left(\mathrm{CD}_{10}\right)\left(10.15 \mathrm{t} \mathrm{ha}^{-1}\right)$ gave higher and statistically similar WEY with the maximum in IPNS $\left(\mathrm{PM}_{6}\right)$. Again, the treatments IPNS $\left(\mathrm{PM}_{3}\right)\left(10.05 \mathrm{tha}^{-1}\right)$ and IPNS (CD $)\left(9.83 \mathrm{t} \mathrm{ha}^{-1}\right)$ also showed similar WEY each other but lower than that of IPNS $\left(\mathrm{CD}_{10}\right)$. The WEY in STB $\left(9.35 \mathrm{t} \mathrm{ha}^{-1}\right)$ and FP $\left(8.26 \mathrm{t} \mathrm{ha}^{-1}\right)$ varied significantly and the lowest one was obtained from FP. System productivity was observed higher with conjunctive use of fertilizer and organic manure (PM and $\mathrm{CD})$. The results in the present study are in agreement with the findings of other researchers who also attained maximum crop productivity by combined application of chemical fertilizers and manures (Yang et al., 2004; Rafique et al., 2012). As organic manure not only provides macro and micro nutrients (Kabeerathumma et al., 1993) but also improves soil physical properties (Bhattacharyya et al., 2004) and soil microbial activities (Tiwari et al., 1998). However, PM produced higher WEY than that of CD. Evidently, the effect of organic amendments depends on how readily organic $\mathrm{N}$ is available. Poultry manure could increase grain yield significantly due to the ready availability of $\mathrm{N}$. These results are in agreement with the findings of Behera (2009) who illustrated that yield of wheat was linearly increased with the total $\mathrm{N}$ inputs through PM being raised from 2.5 to $10 \mathrm{t} \mathrm{ha}^{-1}$. These results suggest that productivity of wheat-rice cropping system cannot only be improved but sustained in the long-run with balanced fertilization and also through combine use of inorganic and nutrient-rich organic manures such as PM. Evidently, the current recommended STB and FP doses were not adequate for the wheat-rice sequence.

\section{Land use efficiency (LUE) and production efficiency (PE)}

The effect of cropping sequence on LUE and PE was significant in both years (Table 5). In general, sequences intensified by legume crops recorded higher LUE than the sequence without legume. The highest LUE $(88.99 \%$ in $2009-10$ and $90.27 \%$ in 2010-11) was recorded in W-B-R. The lowest LUE was recorded in WF-R $(64.66 \%$ in $2009-10$ and $66.07 \%$ in 2010-11). Cropping sequence intensified with blackgram as a grain legume occupied the maximum duration of land resulted in greatest LUE of W-B-R sequence. The sequence having grain legumes generated higher PE value with W-M-R (39.96 kg-1 $\mathrm{ha}^{-1} \mathrm{day}^{-1}$ in 2009-10 and 36.71 $\mathrm{kg}^{-1} \mathrm{ha}^{-1} \mathrm{day}^{-1}$ in 2010-11). The W-F-R was statistically different from all other treatments in 2009-10, but it remained at par with W-B-R in 2010-11. However, 
the sequence W-S-R (having green manuring crop) gave the lowest PE $(26.36 \mathrm{~kg}$ ${ }^{1} \mathrm{ha}^{-1}$ day $^{-1}$ in 2009-10 and 27.24 kg ${ }^{-1} \mathrm{ha}^{-1}$ day $^{-1}$ in 2010-11) among the cropping sequences. The maximum production efficiency was obtained in the wheatmungbean-rice sequence. Mian (2008) observed the highest production efficiency in maize-mungbean-rice among the maize oriented cropping sequences.

The nutrient treatment had significant impact on LUE and PE in both the years 2009-10 and 2010-11 (Table 6). The treatments included by organic manure showed higher LUE than the treatments having chemical fertilizer only in both the years. However, the treatments having organic manures showed more or less similar LUE among themselves. The organic amended treatments ranking in terms of LUE were in the order of IPNS $\left(\mathrm{PM}_{6}\right)>\operatorname{IPNS}\left(\mathrm{CD}_{10}\right)>\operatorname{IPNS}\left(\mathrm{PM}_{3}\right)>\operatorname{IPNS}$ $\left(\mathrm{CD}_{5}\right)$. The other two treatments STB and FP that did not include manure showed statistically identical LUE, where the FP had the lowest LUE in both the years. The nutrient treatments with organic manures recorded higher land use efficiency due to longer duration of component crop in the cropping sequence. During 200910 , the nutrient management IPNS $\left(\mathrm{PM}_{6}\right) \quad\left(36.37 \mathrm{~kg}^{-1} \mathrm{ha}^{-1}\right.$ day-1) gave the maximum PE, which was statistically identical with that of IPNS $\left(\mathrm{CD}_{10}\right) \quad(35.34$ $\left.\mathrm{kg}^{-1} \mathrm{ha}^{-1} \mathrm{day}^{-1}\right)$ due to higher WEY. The PE in IPNS $\left(\mathrm{PM}_{3}\right)$ was $34.79 \mathrm{~kg}^{-1} \mathrm{ha}^{-1} \mathrm{day}^{-}$ ${ }^{1}$, which was identical to IPNS $\left(\mathrm{CD}_{10}\right)$. The PE values in IPNS $\left(\mathrm{CD}_{5}\right)$ and STB were 33.27 and $32.15 \mathrm{~kg}^{-1} \mathrm{ha}^{-1} \mathrm{day}^{-1}$, which were also statistically identical. The lowest PE was recorded in FP $\left(29.14 \mathrm{~kg}^{-1} \mathrm{ha}^{-1} \mathrm{day}^{-1}\right)$. Almost similar trend was observed in 2010-11 as was found in 2009-10.

\section{Partial budget analysis}

Cropping sequence attributed a significant impact on cost of cultivation, gross return, gross margin and benefit cost ratio (BCR) in both the years (Table 7). Both the production costs and annual gross returns were considered for choosing suitable cropping sequence, because these varied widely in different cropping sequences. In general, inclusion of the third crop in the summer season either as grain legume or sesbania for green manuring, markedly enhanced the cost of production. Among the different sequences, W-B-R (Tk. $138075 \mathrm{ha}^{-1}$ in 2009-10 and Tk. $133175 \mathrm{ha}^{-1}$ in 2010-11) and W-M-R (Tk. $134159 \mathrm{ha}^{-1}$ in 2009-10 and Tk. $129259 \mathrm{ha}^{-1}$ in 2010-11) had higher cost of cultivation being the maximum in WB-R due to extra pesticide and labour cost for blackgram cultivation. The other triple cropping sequence W-S-R (Tk. 114344 ha $^{-1}$ in 2009-10 and Tk. 108944 ha $^{-1}$ in 2010-11) recorded intermediate cost of cultivation, whereas the double cropping sequence W-F-R (Tk. 99995 ha $^{-1}$ in 2009-10 and Tk. 94595 ha $^{-1}$ in 2010-11) had the lowest annual cost of cultivation. Annual cost of cultivation increased with increasing cropping intensity, with the triple-cropping system incurring considerable higher costs than the double-cropping system primarily due to cost of fertilizer, labour and plant protection (Biswas et al., 2006; Singh et al., 2011). 
However, cost of cultivation was higher in first year due to higher irrigation cost of rice because of minimum rainfall during the cropping season. The W-M-R had a maximum gross return (Tk. $271371 \mathrm{ha}^{-1}$ in 2009-10 and Tk. $253802 \mathrm{ha}^{-1}$ in 201011), which also recorded highest gross margin (Tk. 137212 ha $^{-1}$ in 2009-10 and Tk. $124543 \mathrm{ha}^{-1}$ in 2010-11) and BCR (2.02 in 2009-10 and 1.96 in 2010-11) than all other cropping sequences. This was mainly due to the production potential accompanied with good monetary returns of mungbean (Singh et al., 1993). Gross margin under sesbania included sequence W-S-R and double cropping sequence W-F-R were statistically identical and lower in both the cropping years. Gross margin under W-S-R and W-F-R sequences were Tk. 66175 and $72528 \mathrm{ha}^{-1}$ in 2009-10 and Tk. 82399 and 81973 ha $^{-1}$ in 2010-11, respectively. Inclusion of sesbania in the sequence W-S-R could not improve the BCR (1.58 in 2009-10 and 1.76 in 2010-11) as a result lower BCR than the W-F-R (1.72 in 2009-10 and 1.87 in 2010-11) sequence. The lowest gross margin and BCR in wheat-sesbania-rice sequence was mainly due to comparatively higher production cost.

The nutrient treatment showed significant effect on different economic parameters in both the years (Table 8). Cost of cultivation in organic manure amended different treatments and soil test based chemical fertilizer were statistically identical, but they were significantly higher than that of farmers' practice in both the years. However, the IPNS treatments with cowdung had numerically higher cost of cultivation due to higher amount of manure. Nonetheless, among the fertilizer treatments ranking in terms of cost of cultivation were in the order of IPNS $\left(\mathrm{CD}_{10}\right)>\mathrm{STB}>\operatorname{IPNS}\left(\mathrm{CD}_{5}\right)>\operatorname{IPNS}\left(\mathrm{PM}_{6}\right)>\operatorname{IPNS}\left(\mathrm{PM}_{3}\right)$ and their corresponding values were Tk. 122668, 122637, 122608, 122446 and 121717 ha ${ }^{1}$, respectively in 2009-10. Similarly, the corresponding values of the treatments in 2010-11 were Tk. 117518, 117487, 117458, 117296 and $116567 \mathrm{ha}^{-1}$, respectively. The highest gross return (Tk. 239287 and 233155 ha $^{-1}$ in 2009-10 and 2010-11, respectively) was recorded in IPNS ( $\left.\mathrm{PM}_{6}\right)$ and the lowest (Tk. 188700 and 184340 $\mathrm{ha}^{-1}$ in 2009-10 and 2010-11, respectively) was in FP. Similar trends were also observed in case of gross margin and BCR in both the years. The fertilizer management treatment IPNS ( $\mathrm{PM}_{6}$ ) showed the highest gross margin (Tk. 116840 and $115858 \mathrm{ha}^{-1}$ in 2009-10 and 2010-11, respectively) and BCR (Tk. 1.94 and $1.99 \mathrm{ha}^{-1}$ in 2009-10 and 2010-11, respectively) among all other treatments. The other manure amended treatments gave the better economic performance compared to STB or FP. Cost of cultivation was the lowest in farmers' fertilizer treatment because of lower fertilizer inputs. Gross return, gross margin and BCR were the highest in IPNS with $6 \mathrm{t} \mathrm{ha}^{-1} \mathrm{PM}$. This was primarily due to higher crop productivity under $6 \mathrm{t} \mathrm{ha}^{-1} \mathrm{PM}$ amended nutrient treatment. However, other organic manure amended treatment also gave the better gross return, gross margin and $\mathrm{BCR}$ because of better performance of the component crop in the sequences. The farmers, fertilizer practice showed the lowest performance in respect of aforesaid economic parameters caused by poorest crop productivity. 


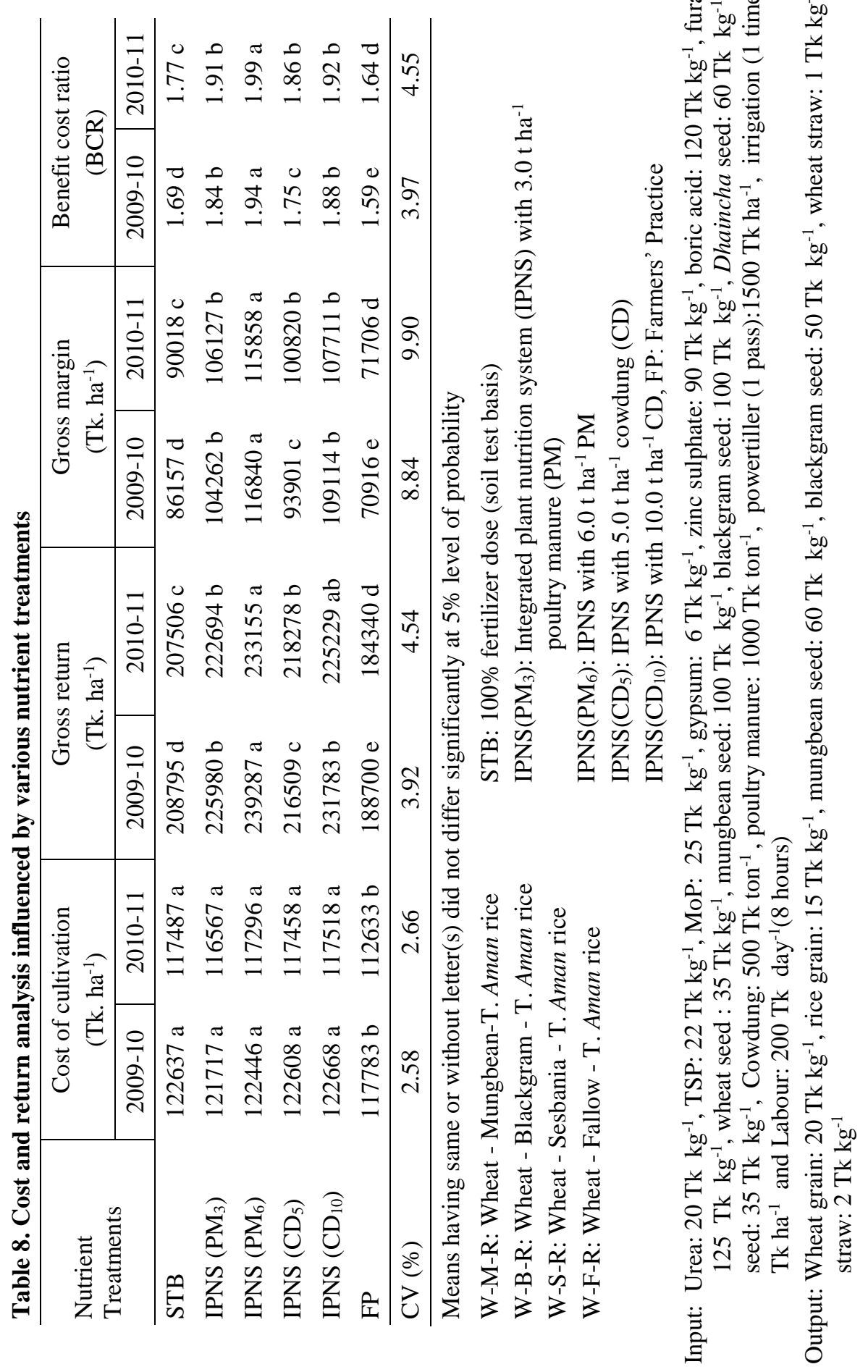

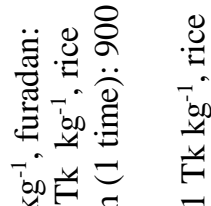

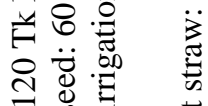

预苛范

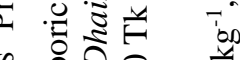

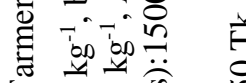

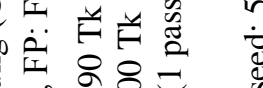

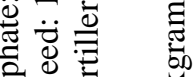


The interaction effect of the cropping sequence and nutrient treatment did not show significant effect on crop productivity, LUE, PE and economic parameters in both the years.

\section{Conclusion}

Inclusion of grain legume in wheat-rice sequence resulted in higher cost, but produced greater annual productivity, gross return, gross margin and benefit cost ratio. Residue recycling of legume crops could partially replace $\mathrm{N}$ fertilizer for rice and had a considerable positive effect, although not significant, on the following wheat crop. Organic manure (particularly PM) played a significant role in increasing the productivity of wheat as well as other component crops in the cropping sequences. So, Wheat-Mungbean-Transplant Aman rice under IPNS with organic manures (CD or PM) can be practiced at farmers' level for greater productivity and profitability and improvement of soil health. Nutrient management packages involving higher rate of organic manure $\left(\mathrm{N}_{74} \mathrm{P}_{0} \mathrm{~K}_{5} \mathrm{~S}_{5} \mathrm{Zn}_{3} \mathrm{~B}_{1}\right.$ $\mathrm{kg} \mathrm{ha}^{-1}+\mathrm{PM} 6 \mathrm{t} \mathrm{ha}^{-1}$ or $\mathrm{N}_{98} \mathrm{P}_{3} \mathrm{~K}_{0} \mathrm{~S}_{5} \mathrm{Zn}_{3} \mathrm{~B}_{1} \mathrm{~kg} \mathrm{ha}^{-1}+\mathrm{CD} 10 \mathrm{tha}^{-1}$ for wheat; $\mathrm{N}_{21} \mathrm{P}_{13} \mathrm{~K}_{17}$ $\mathrm{kg} \mathrm{ha}^{-1}$ for mungbean and $\mathrm{N}_{97} \mathrm{P}_{4} \mathrm{~K}_{17} \mathrm{~S}_{6} \mathrm{Zn}_{2} \mathrm{~kg} \mathrm{ha}^{-1}$ for $\mathrm{T}$. Aman rice) can be the suitable practice. Poultry manure was found more effective than cowdung.

\section{Acknowledgement}

The authors acknowledge the financial support from National Agricultural Technology Project (NATP): Phase-1 of Bangladesh Agricultural Research Council (BARC) to conduct this study.

\section{References}

Ahlawat, I. P. S. and R. P. Sharma. 1993. Agronomic terminology. 3rd ed. New Delhi: Indian Soci. Agron. Pp. 9-16.

Bair, W. 1990. Characterization of the environment for sustainable agriculture in SemiArid Tropics. In: Sustainable Agriculture: Issue, Perspective and prospects in Semi Arid Tropics (Ed. Singh RP), Hyderabad, India. Indian Soci. Agron. 1: 90-128.

BARC (Bangladesh Agricultural Research Council). 2005. Fertilizer Recommendation Guide. BARC, Farmgate, Dhaka 1215, Bangladesh. P. 260.

BARI (Bangladesh Agricultural Research Institute). 2011. Krishi Projukti Hatboi (Handbook on Agro-technology), $5^{\text {th }}$ edi. BARI, Gazipur 1701, Bangladesh. Pp. 107180.

BBS (Bangladesh Bureau of Statitics). 2012. Statistical Yearbook of Bangladesh (31 ${ }^{\text {st }}$ edition), BBS, Statistics \& Informatic Division, Ministry of Planning, Government of the People's Republic of Bangladesh, Dhaka, Bangladesh. Pp. 123-155.

Behera, U. K. 2009. Organic manuring for soil biological health and productivity of a wheat-soybean cropping system in the Vertisols of central India. Crop \& Pasture Sci. 60: $382-393$. 
Bhandari, A. L., J. K. Ladha, H Pathak, A. T. Padre, D. Dawe and R. K. Gupta. 2002. Yield and soil nutrient changes in a long-term rice-wheat rotation in India. Soil Sci. Soci. Ame. J. 66: 162-170.

Bhattacharyya, R., V. Prakash, S. Kundu, A. K. Srivastva and H. S. Gupta. 2004. Effect of long-term manuring on soil organic carbon, bulk density and water retention characteristics under soybean-wheat cropping sequence in north-western Himalayas. J. the Indian Soci. Soil Sci. 52: $238-242$.

Biswas, B., D. C. Ghosh, M. K. Dasgupta, N. Trivedi, J. Timsina and A. Dobermann. 2006. Integrated assessment of cropping systems in the Eastern Indo-Gangetic plain. Field Crops Res. 99: 35-47.

Bohra, J. S., R. K. Singh and Singh Yogeshwar. 2007. Mustard (Brassica juncea): A good option for diversification of rice-wheat system under irrigated ecosystem of North eastern plane zone of India. Paper presented during 26-30 March, 2007. In: Proceedings of the 12th International Rapeseed Congress on 'Sustainable Development in Cruciferous Oilseed Crop Production'; Wuhan, China.

BRRI (Bangladesh Rice Research Institute). 2010. Annual Internal Review Report for 2009-10, BRRI, Gazipur, Bangladesh. P. 265.

Chadha, M.L., Bains, T.S., Sekhon, H.S., Sain, S.K., 2009. Short duration mungbean for diversification of rice-wheat system. Milestones in food legume research II-The Peninsular Region. Kanpur, 151-177.

Eghball, B., B. J. Wienhold, J. E. Gilley and R. A. Eigenberg. 2002. Mineralization of manure nutrients. J. Soil and Water Con. 57: 470-473.

Gomez, K. A. and A. A. Gomez. 1984. Statistical Procedure for Agricultural Research. 2nd Edition International Rice Research Institute, Manila, Philippines. Pp. 139-207.

Hedge, D. M. 1998. Long-term sustainability of productivity in rice (Oryza sativa)-wheat (Triticum aestivum) system in sub humid ecosystem through integrated nutrient supply. Idian J. Agron. 43 (2): 189-198.

Jamwal J. S. 2001: Productivity and economics of different maize (Zea mays) based crop sequences under dryland conditions. Indian J. Agron. 46(4): 601-604.

Kabeerathumma, S., C.R. Mohankumar, G. M. Nair and P. G. Nair. 1993. Effect of continuous cropping of cassava with organics and inorganics on the secondary and micronutrient elements status of an Ultisol. J. the Indian Soci. Soil Sci. 41: 710-713.

Kumar, K. and K. M. Goh. 2000. Crop residue management: Effects on soil quality, soil nitrogen dynamics, crop yield and nitrogen recovery. Adv. Agron. 68: 197-319.

Mian, M. A. K. 2008. Performance of maize oriented cropping patterns under different nutrient management, PhD Dissertation, Department of Agronomy, Bangladesh Agricultural University, Mymensingh.

Nand Ram. 2000. Long-term effects of fertilizers on rice-wheat-cowpea productivity and soil properties in mollisols. In: Abrol, I.P., Bronson, K.F., Duxbury, J.M., Gupta, R.K. (Eds.), Longterm Soil Fertility Experiments in Rice-Wheat Cropping Systems. Rice- 
Wheat Consortium Paper Series 6. Rice-Wheat Consortium for the Indo-Gangetic Plains, New Delhi, Pp. 50-55.

OFRD (On-Farm Research Division) 2009: Annual Research Report 2008-09. OFRD, Bangladesh Agricultural Research Institute, Joydebpur, Gazipur.

Perrin, R. K., D. L. Winkelman, E. R. Moseardi and J. R. Anderson. 1979. Farm agronomic data to farmer's recommendations. Information Bulletin 27, CIMMYT, MEXICO. P. 79 .

Prasad, R., B. Gangaiah and K. C. Aipe. 1999. Effect of crop residue management in a ricewheat cropping system on growth and yield of crops and on soil fertility. Experimental Agricultural. 35: 427-435.

Quayyum M. A., J. Timsina, M. A. H. S. Jahan, R. A. Begum and D. J. Connor. 2002. Grain yield and system productivity for wheat-mungbean-rice and wheat-maize-rice sequences in northern Bangladesh. Thai J. Agril. Sci. 35(1) 51-62.

Rafique, E., M. Mahmood-ul-Hassan, A. Rashid and M. F. Chaudhary. 2012. Nutrient balances as affected by integrated nutrient and crop residue management in cottonwheat system in Aridisols. I. Nitrogen. J. Plant Nutrition. 35: 591-616.

Rahman, M. M. 1991. Factors limiting the expansion of summer pulses. In: Advances in Pulses Research in Bangladesh: Proceedings of the Second National Workshop on Pulses, 6-8 June 1989, BARI, Joydebpur, Bangladesh. ICRISAT, Patancheru, India Publisher, Pp: 29-41.

Samra, J.S., Bijay-Singh and K. Kumar. 2003. Managing Crop Residues in the Rice-Wheat System of the Indo-Gangetic Plain. P. 173-195. In J. K. Ladha et al. (ed.) Improving the productivity and sustainability of rice-wheat systems: Issues and impact. ASA. Spec. Pub. 65, ASA, Madison, Wis.

Schmidt, L. and W. Merbach. 2004. Response of soil C and N content to fertilizationresults of long-term trials at Halle/S. Germany. Archives of Agronomy and Soil Science. 50: 49-57.

Sharma, S. N. and R. Prasad. 1999. Effects of sesbania green manuring and mungbean residue incorporation of productivity and nitrogen uptake of a rice-wheat cropping system. Bioresource Technology. 67: 171-175.

Shepherd, M.A. and P. J. Withers. 1999. Application of poultry litter and triple superphosphate fertilizer to a sandy soil: effect on soil phosphorus status and profile distribution. Nutrient Cycling in Agroecosystems. 54: 233-242.

Singh, G. B. and D. V. Yadav. 1992. Integrated nutrient supply system (INSS) in sugarcane based cropping system. Fertilizer News. 37(4): 15-22.

Singh, M. P., S. C. Verma and R. P. Singh. 1993. Effect on rice-based crop sequences on yield and economic sustainability under irrigated condition of eastern Uttar Pradesh. Ann. Agric. Res. 14: 237-239.

Singh, R. K., J. S. Bohra, T. Nath, Y. Singh and K. Singh. 2011. Integrated assessment of diversification of rice-wheat cropping system in Indo-Gangetic plain. Archives of Agronomy and Soil Science. 57(5): 489-506. 
Tagoe, S.O., T. Horiuchi. and T. Matsui. 2008. Preliminary evaluation of the effects of carbonized chicken manure, refuse derived fuel and $\mathrm{K}$ fertilizer applicaion on the growth, nodulation, yield, $\mathrm{N}$ and $\mathrm{P}$ contents of soybean and cowpea in the greenhouse. African J. Agril. Res. 3(11): 759-774.

Timsina, J. and D. J. Connor. 2001. Productivity and management of rice-wheat cropping systems, issues and challenges. Field Crops Res. 69: 93-132.

Timsina, J., M. L. Jat and K. Majumdar. 2010. Rice-maize systems of South Asia: current status, future prospects and research priorities for nutrient management. Plant Soil. 335: $65-82$.

Tiwari, K.N., G. Dev, D. N. Sharma and U. V. Singh. 1998. Maximizing yield of a ricewheat sequence in recently reclaimed saline-sodic soils. Better Crops International. 12 (2): 9-11.

Yadvinder-Singh, Bijay-Singh, J. K. Ladha, C. S. Khind, R. K. Gupta, O. P. Meelu and E. Pasuquin. 2004. Long-Term Effects of Organic Inputs on Yield and Soil Fertility in the Rice-Wheat Rotation. Soil Sci. Soci. Ame. J. 68: 845-853.

Yadvinder-Singh, Bijay-Singh, R. K. Gupta, J. K. Ladha, J. S. Bains and J. Singh. 2008. Evaluation of press mud cake as a source of nitrogen and phosphorus for rice-wheat cropping system in the Indo-Gangetic plains of India. Biology and Fertility of Soils. 45: 289-296.

Yang, S., F. Li, S. S. Malhi, P. Wang, D. Suo and J. Wang. 2004. Long-term fertilization effects on crop yield and nitrate nitrogen accumulation in soil in north western China. Agron. J. 96: $1039-1049$. 